\title{
MODELLING OF ROCK SLOPE FAILURES DUE TO GEOLOGICAL DISCONTINUTIES TO MINIMIZE RISK FROM ROAD CUT FAILURES
}

\author{
RANJITH PREMASIRI \\ Department of Earth Resources Engineering, University of Moratuwa, Katubedda, \\ Sri Lanka \\ Corresponding Author Email: ranjith@uom.lk
}

(Received 31 ${ }^{\text {st }}$ May 2018; Accepted $30^{\text {th }}$ September 2018)

\begin{abstract}
Rock slope failures are common issues on road cuts. Geological discontinuities are one of main causal factors for the occurrence of rock slope failures and most rocks exposed in road cuts show slope failures as rock falls. Most of the roads constructed across hilly areas have risk from such slope failures resulting in adverse effects on road uses. The aim of the present study is to model rock slope failures which can be used at the design stage to reduce the risk from structural geological features especially planer structures (foliation and joint planes). Two road traces which run across Sri Lankan mountain terrains (Avissawella - Hatton and Balangoda - Haputale roads) were used for the study. Field data on orientation of structural geological features and the type of rock involved in rock falls were collected from 44 locations along both road stretches. Dip Anlysist 2.0 was used for modelling the slope failures. Wedge failure, Toppling and Plane failure modes were considered. Wedge failure is the most common rock slope failure observed. When compared with field observations, the model shows $64 \%$ precision from 44 locations studied. The model revealed that the risk from road cut failures can be minimized by optimising existing road orientation and slope angle of the cut. The slope failures can be reduced by using this type of model analysis during the design stage of new roads.
\end{abstract}

Key words: Cutting, Dip Analyst, failure, Road cut, Rock falls

\section{INTRODUCTION}

Rock falls and rock slope failures are common natural phenomena found in most of the road cuts and other rocky slopes. Rock slope failures occur by creating instability of rock mass on slopes leading to downward movement of these mass mainly by gravity (Wang and Niu, 2009; Raja, 2013). In Sri Lanka, most of roads across hilly areas are constructed by using cut and fill method. Very often these road cuts generate unstable condition of the ground leading to slope failures. This phenomenon is very common in hilly areas of Central
Sri Lanka due to poorly designed road construction. In general, Central part of Sri Lanka is underlain by highly deformed metamorphic rocks subjected to various grades of weathering (Jayawardena and Eiji Izawa, 1994). These deformed metamorphic rocks are formed by multiple deformational events (Berger and Jayasinghe, 1976). Geological structures such as joints and fractures along with strongly developed foliation planes create some weaker geological surfaces in metamorphic rocks (Figure 1). Most of the road cuts with exposed rocks associated with such structures show rock falls as common slope failures. 
Hence, some parts of the roads carry risk of rock falls which is a safety issue for the road and for its users. Vulnerability of failures of road cuts spreads over several districts in Sri Lanka namely Badulla, Rathnapura, Kegalle and Kandy (Bandara, 2015). Most of the roads constructed in the hilly areas face the problem of rock falls thereby roads getting obstructed, mostly in every rainy season of the year. It creates many environmental and social issues and property damages which affect the day to day life of the people and economy of the country. Most of rock slope failures occur on road cuts are due to many factors such as rock types, geological discontinuities, rock weathering condition, climatic parameters, groundwater condition, slope angle, orientation of the road and ground vibrations (Braathen et al., 2004; Wyrwoll, 1977). Very often geotechnical properties such as strength and weathering conditions of rocks and hydrological condition such as groundwater and surface water conditions are used in slope stabilizations process. Though, road cuts are designed mostly using such geochemical and hydrological parameters, the presence of geological discontinuities is not considered when designing road cut slopes. Main geological discontinuities are bedding planes, foliation planes, joint or fracture planes, fault planes, shear zones and exfoliation plane (Bhasin and Kaynia, 2004) which are also make considerable impact on slope failures. However, the existence of geological discontinuities and their impacts on rock slope failures are beyond the control of the designers. But out of other factors, slope angle and the orientation of the road are controllable factors. Therefore, modification of slope parameters is one of available mitigative or preventive methods (Cundall, 1971; Hoek et al., 2000) of rock slope failures.

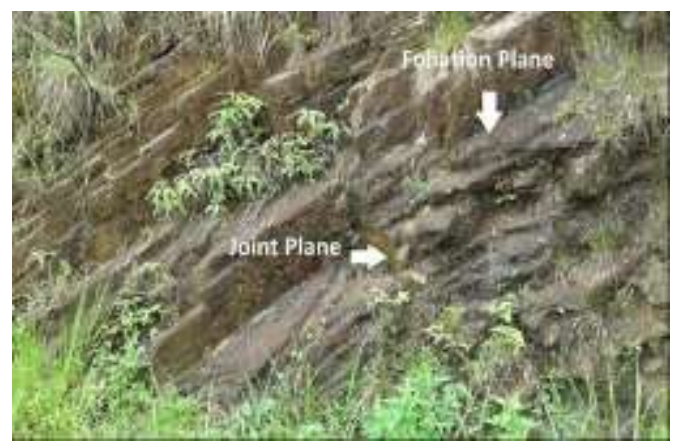

Fig. 1. An image showing rock outcrop with strongly developed major geological discontinuity planes such as foliation and joints planes. Location - road cut along Balangoda- Haputale road.

Rock slopes become more vulnerable to rock falling under the influence of factors such as heavy rainfall due to considering all affecting factors for road cut failures such as geological condition, geotechnical properties, seismic activity, dynamic loading, and some human interventions (Bhasin and Kayania, 2004). Most of road stretches in hilly areas of Sri Lanka become susceptible to slope failures creating some risk for road users, due to lack of interest in such parameters during design stage. Thus, the main objective of the study is to model rock slope failures by using Dip Anlysist software and by modifying road orientation and slope angles of the road cut to minimize rock slope failures. The major parameters of the model are geological discontinuities of rocks which are currently not incorporated into determining optimum safety condition of roads.

\section{METHODOLOGY}

Two road stretches; from AvissawellaHatton road and Balangoda-Haputale roads were selected as the study area and data from 44 locations along were collected for this study (Figure 2). 
These two roads fall mostly in the western and southwestern slopes of the central highlands of Sri Lanka. Geologically the study area belongs to granulite grade metamorphic rock terrain of Sri Lanka, which mainly comprises charnockite, charnockitic gneisses, quartzite and other highgrade gneisses. The rock in this metamorphic terrain has been subjected to several metamorphic and deformational events (Cooray, 1994). Hence, the rocks of the area contain complex and highly deformed geological structural features. Geomorphologically, the study areas comprise ridge and valley topography. with steep slopes, since both areas fall within escarp areas in between peneplains of Sri Lanka.

The southwestern part of Sri Lanka belongs to wet climatic zones, which receives $2500-5000 \mathrm{~mm}$ annual average rainfall. Field measurements were made on mainly fresh rock outcrops during the dry seasons of the year. Observations were made on type of rock and weathering condition. And angle and direction of dip, direction of strike of major foliation plane and all joint planes, slope of the road cut and direction of slope were measured at each location.

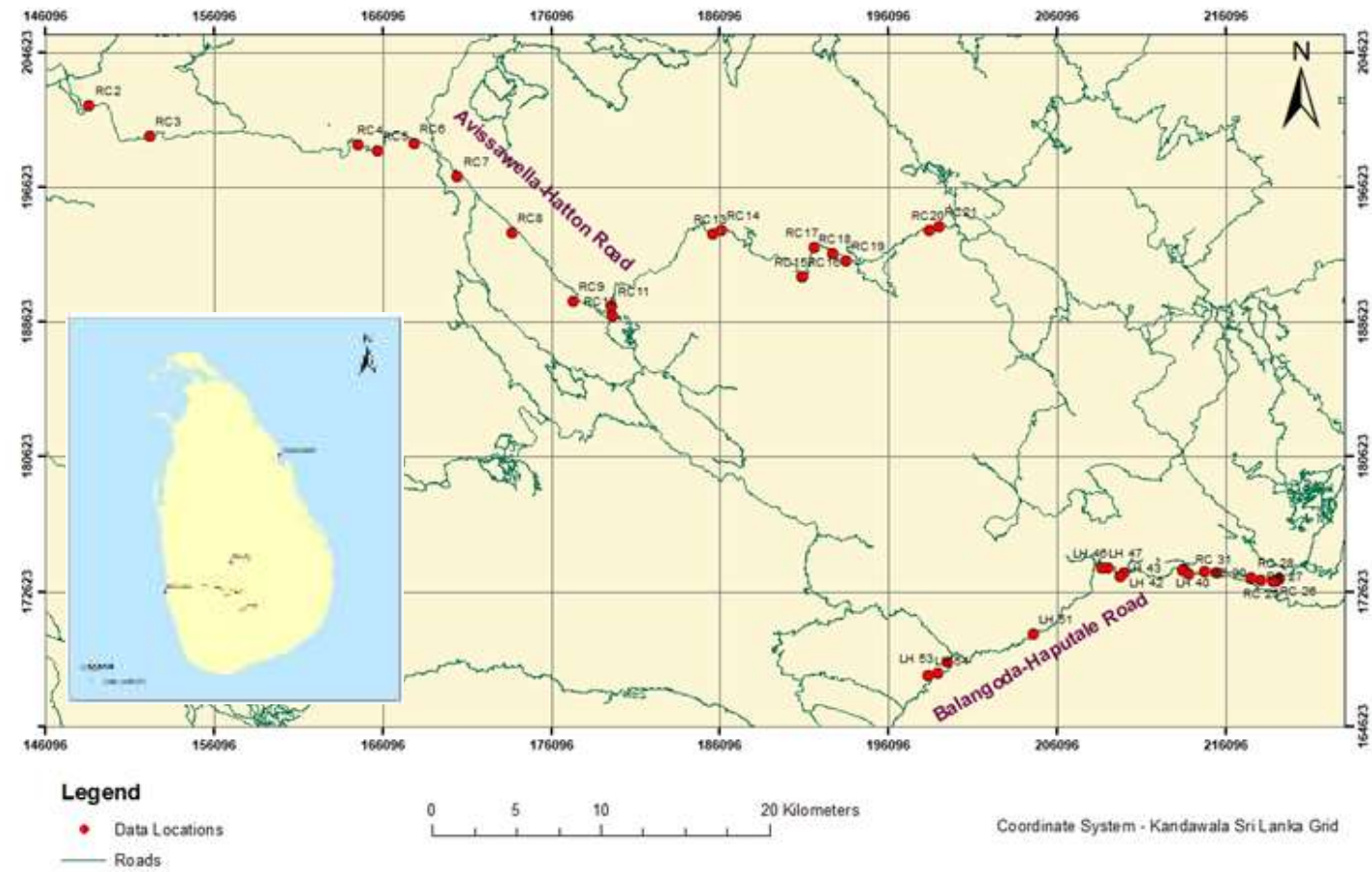

Fig. 2. Map of the study area, Avissawella-Hatton road and Balangoda-Haputale road.

\section{ANALYSIS OF SLOPE FAILURES BY DIPANALYSIST SOFTWARE}

Input parameters considered to determine failure indexes using Dip Analysist are direction of strike (bearing), angle of dip and dip direction of geological planes, and road direction and slope angle of road cut. Additionally, it needs friction angle of the rock mass, which has to be estimated. In the present study, it was estimated using available literature (Premasiri et al., 2016). Then friction angles were taken as $38^{\circ}$ (for fresh rock), $33^{0}$ (for slightly weathered rock) 
and $24^{0}$ (for moderately weathered weak rocks)

\section{RESULTS AND DISCUSSION}

Most of the rock falls have taken place along geological discontinuities such as foliation planes and joint/fracture planes of rocks (Figure 1). Both road stretches studied indicate that the rock exposures on the road cut comprised high grade hard crystalline metamorphic rocks such as charnockite, charnockitic gneisses, garnet biotite gneisses, garnet granulite and quartzite. These rocks exhibit differently developed foliation and joint planes as major geological discontinuities. Fifteen locations of massive charnockite, 13 locations of Charnockitic gneiss, 5 locations of garnet biotite/or garnet granulitic gneiss and 11 locations of quartzite (Table 1) are observed at the 44 locations subjected to the study.

\section{SLOPE FAILURE ANALYSIS}

Failure index analysis of 44 locations showed that the most prominent failure was the wedge failure which observed at 20 locations out of 44 (Figure 3a). Toppling failures were observed at 6 locations (Figure 3b) while plane failures were observed at 9 locations (Figure 3c). When, the results of the numerical analysis are compared with ground observations, $64 \%$ of the results are compatible with the reality (Table 2).

Results derived from the model reveal that the slope should generally be modified from $7^{0}$ to $38^{\circ}$ angles from the existing slope angle to get optimum safety condition, whereas at some locations, road direction has to be modified greatly up to $70^{0}$ to get the required safety condition, which is not practicable. The field observations indicate that slope angle could be modified at many locations to minimise the risk of rock falls rather than modifying the road direction (Table 3 ).
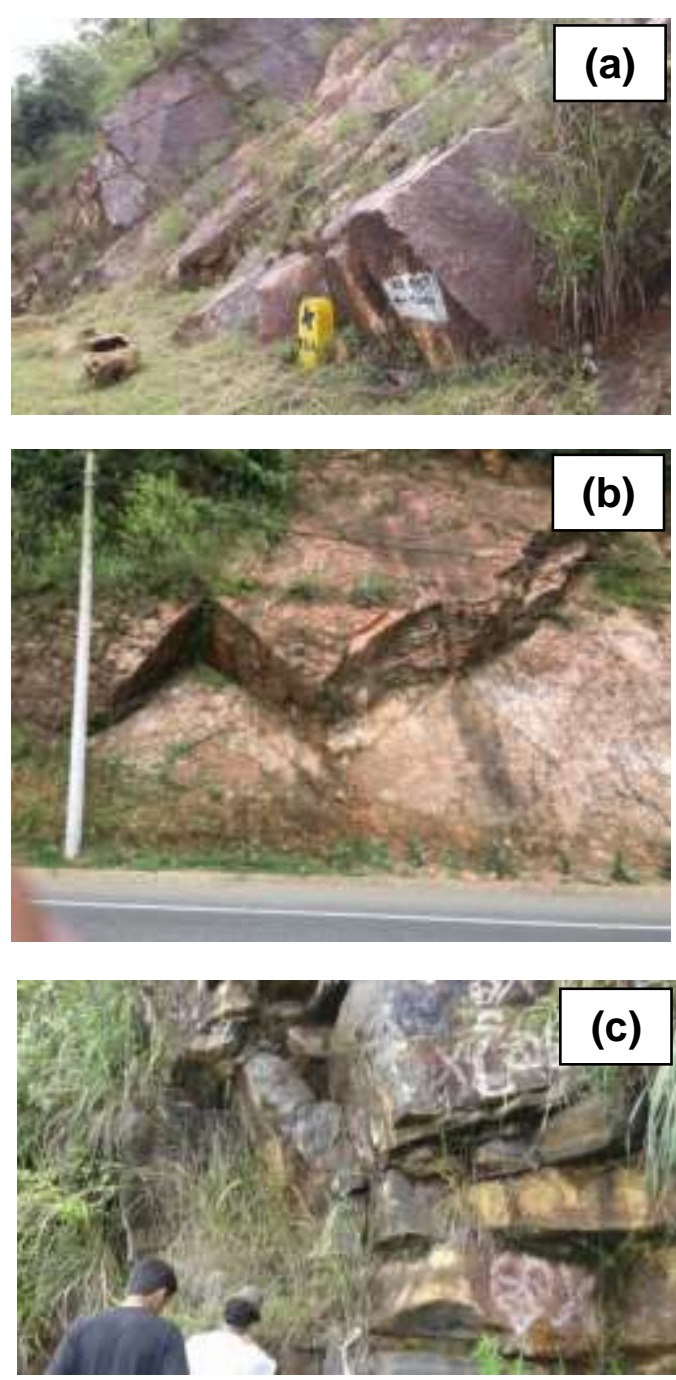

Fig. 3. (a) Plan failure on a road cut along Balangoda- Haputale road. (b) Wedge failure on a road cut along Balangoda- Haputale road. (c) Toppling failure on a road cut along Balangoda- Haputale road. 
Table 1. Failure Index obtained from model and Field observations

\begin{tabular}{|c|c|c|c|c|c|c|}
\hline Location & $\begin{array}{l}\text { Plane } \\
\text { Failure } \\
\text { Index }\end{array}$ & $\begin{array}{l}\text { Wedge } \\
\text { Failure } \\
\text { Index }\end{array}$ & $\begin{array}{l}\text { Toppling } \\
\text { Failure } \\
\text { Index }\end{array}$ & $\begin{array}{l}\text { Ground } \\
\text { Observation } \\
\text { on rock falls }\end{array}$ & $\begin{array}{l}\text { Compatibility } \\
\text { between } \\
\text { model and the } \\
\text { observation }\end{array}$ & $\begin{array}{l}\text { Rock type and } \\
\text { weathering } \\
\text { condition }\end{array}$ \\
\hline $\mathrm{RC} 1$ & 0 & 0 & 0 & non & high & Gt-Bt Gneiss (F) \\
\hline $\mathrm{RC} 2$ & 0.33 & 1 & 0 & gentle & Low & Charnockite (F) \\
\hline M RC3 & 0 & 0 & 0.25 & minor & high & Charnockite ( F) \\
\hline $\mathrm{RC} 4$ & 0 & 0 & 0 & minor & High & Quartzite (F) \\
\hline $\mathrm{RC} 5$ & 0 & 0 & 0.5 & heavily & Low & Charnockite (F) \\
\hline RC6 & 0 & 0 & 0 & non & high & Gt-Bt Gneiss (F) \\
\hline $\mathrm{RC7}$ & 0 & 0 & 0 & minor & Moderate & Gt-Granulite (F) \\
\hline $\mathrm{RC} 8$ & 0.5 & 1 & 0 & gentle & Moderate & Charnockite (W) \\
\hline $\mathrm{RC} 9$ & 0 & 0.33 & 0 & gentle & high & Ch-Gneiss (W) \\
\hline RC10 & 0.5 & 1 & 0 & minor & Low & Charnockite (F) \\
\hline RC11 & 0 & 0 & 0 & gentle & Low & Quartzite (F) \\
\hline $\mathrm{RC} 12$ & 0 & 0 & 0 & non & high & Ch-Gneiss (F) \\
\hline $\mathrm{RC} 13$ & 0 & 0 & 0.33 & minor & high & Charnockite (F) \\
\hline $\mathrm{RC} 14$ & 0 & 0 & 0 & non & high & Ch-Gneiss (W) \\
\hline RC15 & 0 & 0.33 & 0 & heavily & Low & Ch-Gneiss (W) \\
\hline RC16 & 0.33 & 0.67 & 0 & heavily & high & Ch-Gneiss (W) \\
\hline $\mathrm{RC} 17$ & 0 & 0.33 & 0.33 & gentle & high & Ch-Gneiss (W) \\
\hline RC18 & 0 & 0.33 & 0.33 & gentle & Moderate & Ch-Gneiss (F) \\
\hline RC19 & 0 & 0 & 0 & non & high & Charnockite (W) \\
\hline $\mathrm{RC} 20$ & 0 & 0 & 0 & non & high & Ch-Gneiss (F) \\
\hline $\mathrm{RC} 21$ & 0.5 & 0 & 0 & gentle & high & $\begin{array}{l}\text { Charnockite } \\
\text { MW) }\end{array}$ \\
\hline $\mathrm{RC} 22$ & 0 & 0 & 0 & non & high & Charnockite (F) \\
\hline $\mathrm{RC} 23$ & 0 & 0 & 0 & gentle & Moderate & Ch-Gneiss (W) \\
\hline $\mathrm{RC} 24$ & 0 & 0 & 0 & non & high & Charnockite (W) \\
\hline $\mathrm{RC} 25$ & 0 & 0 & 0 & minor & Moderate & Ch-Gneiss (W) \\
\hline $\mathrm{RC} 26$ & 0.33 & 0.33 & 0 & minor & non & Charnockite (W) \\
\hline $\mathrm{RC} 27$ & 0 & 0 & 0 & gentle & non & Charnockite $(\mathrm{F})$ \\
\hline $\mathrm{RC} 28$ & 0 & 0 & 0 & non & high & Charnockite (F) \\
\hline $\mathrm{RC} 29$ & 0 & 0 & 0 & minor & High & Charnockite (F) \\
\hline RC30 & 0 & 0 & 0 & gentle & non & Ch-Gneiss (F) \\
\hline RC31 & 0 & 0 & 0 & heavily & non & Quartzite (W) \\
\hline $\mathrm{RC} 32$ & 0 & 0 & 0.5 & heavily & Low & Quartzite (MW) \\
\hline $\mathrm{RC} 33$ & 0 & 1 & 0 & minor & high & Gt-Bt Gneiss $(\mathrm{F})$ \\
\hline RC34 & 0.33 & 0.33 & 0 & gentle & Moderate & Quartzite (F) \\
\hline RC35 & 0 & 0 & 0 & gentle & non & Quartzite (W) \\
\hline RC36 & 0 & 0 & 0 & gentle & non & Charnockite (F) \\
\hline $\mathrm{RC} 37$ & 0 & 0.33 & 0 & minor & high & Quartzite (W) \\
\hline RC38 & 0.33 & 0.33 & 0 & gentle & High & Gt-Bt Gneiss (F) \\
\hline RC39 & 0 & 0 & 0 & minor & Low & Ch- Gneiss (F) \\
\hline $\mathrm{RC} 40$ & 0 & 0.25 & 0 & non & Low & Quartzite (MW) \\
\hline $\mathrm{RC} 41$ & 0 & 0 & 0 & gentle & non & Ch- Gneiss (F) \\
\hline $\mathrm{RC} 42$ & 0.33 & 0.33 & 0 & minor & Non & Quartzite (F) \\
\hline $\mathrm{RC} 43$ & 0 & 0 & 0 & minor & High & Charnockite (F) \\
\hline $\mathrm{RC} 44$ & 0 & 0.33 & 0 & minor & high & Charnockite (W) \\
\hline
\end{tabular}

\section{VALIDATION OF THE MODEL}

When failure indexes obtained from the model are compared with field observation, it was found that $50 \%$ is highly compatible while $14 \%$ is moderately compatible with the modelled results. However, $18 \%$ of the locations indicate completely opposite relation showing non-compatibility (Table 2). 
Mostly, geotechnical and hydrological conditions are used for road designing and constructions, but geological discontinuities are very often not taken into consideration for rock designing. Thus, major geological discontinuities found in metamorphic rocks are foliation planes and joint planes which were used in the present study to assess the contribution of such failures towards rock slope failures. But intensity of discontinuity planes and weathering condition of the geological structures were not taken into consideration. And the type of the rock with mineralogical composition and their susceptibility to weathering were also not accounted. Therefore, there are some disparities with the model developed by the software and the field observations. But the model is reasonably compatible with $64 \%$ of the ground observations.

Table 2. Compatibility of software modeled failure indexes and field observations

\begin{tabular}{|c|c|c|}
\hline $\begin{array}{c}\text { Compatibi } \\
\text { lity level } \\
\end{array}$ & Locations & $\begin{array}{c}\text { Percent } \\
\text { age }\end{array}$ \\
\hline High & $\begin{array}{l}\text { RC1, RC3, RC4, } \\
\text { RC6, RC9, RC12, } \\
\text { RC13, RC14, } \\
\text { RC16, RC17, } \\
\text { RC19, RC20, } \\
\text { RC21, RC22, } \\
\text { RC24, RC28, } \\
\text { RC29, RC33, } \\
\text { RC37, RC38, } \\
\text { RC43, RC44 } \\
\text { (Total=22) }\end{array}$ & $50 \%$ \\
\hline Moderate & $\begin{array}{l}\mathrm{RC} 7, \mathrm{RC} 8, \mathrm{RC} 18, \\
\mathrm{RC} 23, \mathrm{RC} 25, \\
\mathrm{RC} 34 \\
\text { (Total=6) }\end{array}$ & $14 \%$ \\
\hline Low & $\begin{array}{l}\mathrm{RC} 2, \mathrm{RC} 5, \mathrm{RC} 10, \\
\mathrm{RC} 11, \mathrm{RC} 15, \\
\mathrm{RC} 32, \mathrm{RC} 39, \mathrm{RC} 4 \\
(\text { Total=8) }\end{array}$ & $18 \%$ \\
\hline Non & $\begin{array}{l}\text { RC26, RC27, } \\
\text { RC30, RC31, } \\
\text { RC35, RC36, } \\
\text { RC41, RC42 } \\
\text { (Total =8) }\end{array}$ & $18 \%$ \\
\hline
\end{tabular}

\section{CONCLUSIONS}

Both road stretches (BalangodaHaputale and Avissawella-Hatton) used for this study have similar environmental and geological conditions. Both areas belong to wet climatic zones and to high grade metamorphic rock terrain of Sri Lanka. Therefore, factors which affect rock falls, such as rock weathering, ground water conditions and rain fall affect the model. Rock slope failures at Locations RC1 to RC21 fall within Avissawella-Hatton road and RC22 to RC44 fall within Balangoda-Haputale road (Figure 2) did not show greater variation though these two roads run across western and southern slope of Sri Lankan Central Highlands and also lithological and structural geological features of both areas show similar in condition.

One of the main constrains of this study was determination of suitable friction angle. Considering the rock type and available literature, estimated friction angle values were taken.

When designing roads in hilly areas, modeling of rock slope failures using a computer model is helpful to minimize the risk of rock slope failures. Occurrence of rock slope failures can be minimized by changing road cut direction and the slope angle. According to field observations and results obtained from the model, it can be concluded that nature of structural geological features are the most prominent factors for the occurrence of rock slope failures. Occurrence of rock slope failures does have a direct correlation to type of rocks exposed on road cuts in both road stretches (Table 2). In these roads, road cut failure is a crucial problem due to rock fall which takes place frequently. 


\section{RECOMMENDATIONS}

The results obtained from the model can be used at the design stage of road construction to minimize the future risk of road cut failures.

Type and nature of road cut failures (rock, soil or mud failure) depend on the rock type, mineral composition and weathering conditions which are currently used for stabilizing slope failures. The developed model in the present study is applicable in analyzing rock slope failures. This model can be used as additional information when designing road cuts with currently practicing slope stabilization process which are mainly based on geotechnical properties and hydrological conditions to minimize the road cut failures. The results of the study (Table 2) reveal that $64 \%$ of the locations show comparability between modeled data and field

\section{REFERENCES}

Bandara, R.M.S. (2015). NBRO report http://www.mpid.gov.lk/en/images/NPA_ UNDP/9_Mr_Bandara_plantation_final_3 0-4-2015. pdf. (Accessed on March 2017).

Berger, A.R. and Jayasinghe, N.R. (1976). Precambrian structure and chronology in the Highland Series of Sri Lanka. Precambrian Research, Vol. 3, 559-576.

Bhasin, R. and Kaynia, A.M. (2004). Static and dynamic simulation of a 700-m high rock slope failure in Western Norway, Engineering Geology, Vol. 71, No. 3-4, 213-226.

Braathen, A., Blikra, L. H., Berg, S. S. and Karlsen, F. (2004). Rock-slope failures in Norway; type, geometry,deformation echanisms and stability. Norwegian Journal of Geology/Norsk Geologisk Forening, 84(1).

Cooray, P.G. (1994). The Precambrian of Sri Lanka: a historic review. Precambrian Research, 66: 3-18.

Cundall, P. A. (1971). A Computer model for simulating progressive large-scale movements in blocky rock system, International Proceedings Symposium, ISRM, Nancy, 128-132. observations. Thus, Dip Analysist 2.0

software model gives reasonable accuracy about potential rock slope failures.

\section{ACKNOWLEDGEMENTS}

The author wishes to thank Assistant Professor Yonathan Admassu, James Madison University for granting permission to use Dip Analyst 2.0 software and Mr. S. Weerwranakula and the student team from the Department of Earth Resources Engineering, University of Moratuwa for providing their service during the field visits. The author also wishes to thank Mr. J.D.S.U. Jayakodi for assistance given for GIS analysis. Finally, thanks also go to University of Moratuwa for Providing SRC grant (no SRC/ST/2013/13) to carry out the research.

Hoek, E., Read, J., Karzulovic A. and Chen, Z.Y. (2000). Rock slopes in Civil and Mining Engineering, International Conference on Geotechnical and Geological Engineering, Melbourne, 117.

http://www.dipanalyst.com/Using\%20DipAnal yst/Using\%20DipAnalyst.htmln (Accessed on April 2016).

Jayawardena, U. de S. and Izawa, E. ( 1994). A new chemical index of weathering for metamorphic silicate rocks in tropical regions: A study from Sri Lanka, Engineering Geology, Vol. 36, Issues 34, 303-310.

Premasiri H.M.R., Senarathna C.S.S., Godaliyadda D.P., Disanayake K.T.D., Abeysinghe A.M.K.B. and Weerawarnakula S. (2016). Analysis of geological structures for road cut failures: A case study along Balangoda Haputale Main Road. - Proceedings of National Conference; ERE 2016, Colombo Sri Lanka.

Raja, S. (2013). Influence of structural discontinuities on slope stability, MSc Thesis, submitted to National Institute of Technology, Karnataka India.

Wang, X. and Niu, R. (2009). Spatial forecast of landslides in three gorges based on 
spatial data mining Sensors, 9, 20352061

Wyrwoll, K. H. (1977). Causes of rock-slope failure in a cold area: Labrador-Ungava.
Geological Society of America Reviews in Engineering Geology, Vol. 3, 59-67.

Wyllie, C. and Chris, M. (2004). Rock Slope Engineering, Fourth Edition: Spon Press, London. 